\title{
Efficacy and selectivity of alternative herbicides to glyphosate on maize
}

\author{
Ana Ligia Giraldeli ${ }^{1}$, Gustavo Soares da Silva ${ }^{1}$, André Felipe Moreira Silva ${ }^{1 *}$ D, Giovani Apolari Ghirardello ${ }^{1}$, \\ Lucas Rafael de Marcol, Ricardo Victoria Filho
}

10.1590/0034-737X201966040006

\begin{abstract}
The aim was to evaluate the selectivity and weed control of herbicides atrazine, nicosulfuron, mesotrione and tembotrione, applied alone and associated, in post-emergence of maize. Were carried out two experiments, one in the field in a randomized complete block design with four replications and eleven treatments, the second in greenhouse in a completely randomized design, with four replications and ten treatments. The treatments were composed of isolated and associated herbicides. Treatments were applied V4 stage of plants. For first experiment, crop injury and control evaluations were performed, as well as variables related to agronomic performance (plant height, ear insertion height, prolificacy index, yield and mass of 1,000 grains) and mass of weeds. For second experiment, evaluations of crop injury, height, diameter and dry mass of plants were performed. The lower yield for experiment one was verified in the treatment where only mesotrione was applied, which was attributed to the lower control of monocotyledons weeds. Crop injury were observed at 21 DAA in both experiments, but not exceeding 7.5\%. All treatments were considered selective to maize. The herbicides atrazine, nicosulfuron, mesotrione and tembotrione, at associations, were effective in the weed control, except the association atrazine + mesotrione.
\end{abstract}

Keywords: atrazine; nicosulfuron; mesotrione; tembotrione; Zea mays L.

\section{INTRODUCTION}

Maize (Zea mays L.) has high yield potential, which guarantees high yield in Brazil, mainly due to $\mathrm{C} 4$ metabolism and its physiological characteristics (Fancelli \& Dourado Neto, 2000). In 2017/2018 season the total area sown with crop maize was 16,614 .4 thousand hectares, with a yield of 4,857 kg per hectare and production of 80,709.5 thousand tons (Companhia Nacional de Abastecimento - Conab 2019).

Several factors interfere in the maize yield, among them weeds. In Brazil, several monocotyledons and eudicotyledons species are common in crops such as Amaranthus sp., Cardiospermum halicacabum, Bidens sp., Euphorbia heterophylla, Ipomoea sp., Raphanus sativus, Richardia brasiliensis, Commelina benghalensis, Sida sp., Urochloa sp., Cenchrus echinatus, Digitaria sp., Echinochloa sp., Eleusine indica and Panicum maximum (Borém et al., 2015). The chemical control is the main method used in the control of weeds and the herbicides are applied according to the time of application: pre-planting, pre-emergence and initial and late post-emergence (Oliveira Júnior, 2011).

With the advent of glyphosate-tolerant crops, the use of glyphosate herbicide was intensified. Correa \& Alves (2009), Ramires et al. (2010), Oliveira Neto et al. (2013), among others, report their efficacy in weed control. However, with continued use of the herbicide glyphosate over the years, it has selected resistant weed biotypes.

In Brazil, there are 50 cases of weeds resistant to one or more herbicides belonging to one or more mechanisms of action. Of these, 8 species present resistance to glyphosate, 6 of them being verified in maize crop (Heap, 2019).

\footnotetext{
Submitted on April 29 2019 and accepted on August 14 ${ }^{\text {th }}, 2019$.

${ }^{1}$ Universidade de São Paulo, Escola Superior de Agricultura "Luiz de Queiroz”, Departamento de Produção Vegetal, Piracicaba, São Paulo, Brazil. analigia_giraldeli@hotmail.com; gustavusoares@gmail.com; afmoreirasilva@hotmail.com; giovaniapolari@gmail.com; lucas.marco@usp.br; rvictori@usp.br

*Corresponding author: afmoreirasilva@ hotmail.com
} 
To minimize problems caused by weeds, tolerant or resistant, Green (2012) and Riar et al. (2013) emphasize the importance of integrated weed management, which includes crop rotation and rotation of herbicide mechanisms of action. Besides that, Gazziero (2015) emphasizes the importance of further studies on the herbicide tank mixture, demonstrated in its work that $97 \%$ of the farmers make mixtures of more than one product per spray tank.

As herbicides alternative to glyphosate, used in postemergence of maize, are applied atrazine, nicosulfuron, mesotrione, tembotrione and others, alone or in mixtures (Rodrigues \& Almeida, 2018). Studies highlight the efficacy and/or selectivity of these herbicides in maize, however most often in association with glyphosate (Soltani et al., 2010; Chahal et al., 2018; Giovanelli et al., 2018). There are few recent studies evaluating efficacy and/or selectivity of these herbicides, without association with glyphosate, in maize. This highlight the importance of studies of the efficacy and selectivity of the other herbicides, beyond glyphosate, used in the maize.

It is believed that atrazine, nicosulfuron, mesotrione and tembotrione, may be alternative herbicides to glyphosate for management of weeds in maize. The aim was to evaluate the selectivity and weed control of atrazine, nicosulfuron, mesotrione and tembotrione, applied alone and associated, in post-emergence of maize.

\section{MATERIAL AND METHODS}

\section{Conditions and experimental design}

Two experiments were carried out in the 2016/17 season, in the Piracicaba, state of São Paulo (SP), Brazil. Experiment I was conducted in the field $\left(22^{\circ} 42^{\prime} 51.4^{\prime \prime S}\right.$ $\left.47^{\circ} 37^{\prime} 22.0^{\prime \prime} \mathrm{W}\right)$, and the experiment II was conducted under greenhouse conditions (2242’32.0"S 47³7’43.1"W).

The climate is characterized as Cwa (humid subtropical with drought in the winter) by the climatic classification of Köppen. Figure 1 shows the rainfall and temperature distribution throughout the period of conduction of the experiment $\mathrm{I}$ in the field.

Table 1 shows the chemical and physical analysis of the soil of the experimental area and the soil used to fill the pots of the experiment II in the greenhouse. Conventional maize hybrid 30F53, which has an early cycle, has been adapted for almost all regions of the country. Experiment I was installed in a fallow area, with soybean cultivation in the previous summer crop, conducted between December 2016 and March 2017.

The experimental design was a randomized complete block for experiment I and completely randomized for experiment II, with four replications and 11 treatments for experiment I (Table 2). The same treatments herbicides were used for experiment II, with only one control treatment (without application). The application of the treatments was at the post-emergence of maize plants (V4 development stage), was used $\mathrm{CO}_{2}$ pressurized spray, equipped with a bar with four nozzles, at a constant pressure of $200 \mathrm{kPa}$, providing an application volume of $200 \mathrm{Lha}^{-1}$ and velocity of $1 \mathrm{~m} \mathrm{~s}^{-1}$, with the nozzles positioned at a height of $50 \mathrm{~cm}$ from the plants.

In the experiment $\mathrm{I}$ the experimental units were composed of parcels of $5 \mathrm{~m}$ in length and five rows of maize, with spacing between rows of $0.90 \mathrm{~m}$, being considered useful area the three central lines, discarding the first and last meter of the parcel. In the experiment II, the experimental units were composed of $7 \mathrm{~L}$ pots filled with medium texture soil. Five seeds were sown per pot and after emergence, thinning was done leaving two plants per pot. It is noteworthy that for experiment II the experimental units were kept free from weed interference through weeding.

At the time of application, the field of the experiment I was under natural infestation of several weed species: $C$. benghalensis, U. decumbens, Digitaria sp., E. heterophylla, Ageratum conyzoides, Bidens sp., Ipomoea sp., and Alternanthera tenella.

\section{Evaluations and data collection}

The crop injury and weed control were evaluated by means of visual evaluations, in which percentages ranged from 0 to $100 \%$ in each experimental unit (where 0 represents no symptoms of injury and $100 \%$ death of plants), considering in this case symptoms significantly visible in the plants, according to their development (Velini et al., 1995). These evaluations were performed for experiment I at 7, 14, 21, 28, 35 and 42 days after application (DAA). For the experiment II only the evaluation of crop injury at 7, 14, 21 and 28 DAA.

In the experiment I, at $42 \mathrm{DAA}$ the shoot of remaining weeds of each plot was collected, with a square with an area of $0.25 \mathrm{~m}^{2}$ (two replicates per plot). The material was dried in an oven with forced air ventilation for $72 \mathrm{~h}$ at $65^{\circ} \mathrm{C}$ and to measure the masses, an analytical balance was used with precision of three decimal places.

For experiment I, was performed evaluation of variables related to agronomic performance (plant height, ear insertion height, prolificacy index, yield and mass of 1,000 grains).

For the measurement of the variables: total plant height (from the soil surface to the insertion of the male inflorescence - tassel) and height of the ear insertion (from the soil surface to the ear insertion) were evaluated ten plants of the useful area per plot. A millimeter ruler was used, with the results expressed in meters. 
For the determination of the prolificacy index, the number of ears per plants was counted, with the values obtained divided by 10 , number of plants evaluated from the useful area of each parcel.

Yield estimation was carried out with the ear of the area of the plots manually harvested and threshed in a thresher for experiments, cleaned with the aid of sieves and placed in paper bags. The grains produced in each parcel had their weight measured and the moisture corrected to $13 \%$, from these data the yield was calculated in $\mathrm{tha}^{-1}$. For the mass of one thousand grains the mass of two sub-samples per plot was measured and the moisture corrected to $13 \%$.

For the experiment II, height evaluation was performed at 7, 14, 21 and 28 DAA. The two plants of each pot were measured, millimeter ruler was used, with results expressed in centimeters. At 28 DAA the shoot of each plant was collected to measure the dry matter mass. For drying oven with forced ventilation was used for $72 \mathrm{~h}$ at $65^{\circ} \mathrm{C}$ and to measure the masses, an analytical balance was used with precision of three decimal places.

\section{Statistical analysis}

It was performed analysis of variance by the F-test ( $p$ $<0.05)$ and the means of the treatments were compared by Tukey's (1949) test $(p<0.05)$ (Pimentel-Gomes \& Garcia, 2002). For this purpose, the Sisvar 5.6 software was used (Ferreira, 2011). For crop injury, data were analyzed descriptively by percentage scale.

\section{RESULTS}

In the experiment I, at 7 DAA, injury was observed for nicosulfuron $(6.8 \%)$, atrazine + nicosulfuron $(5 \%)$ and mesotrione + nicosulfuron $(6.3 \%)$ treatments. At 14 DAA

\section{Season 2016/17, Piracicaba - SP \\ 01/11/2016 - 30/03/2017}

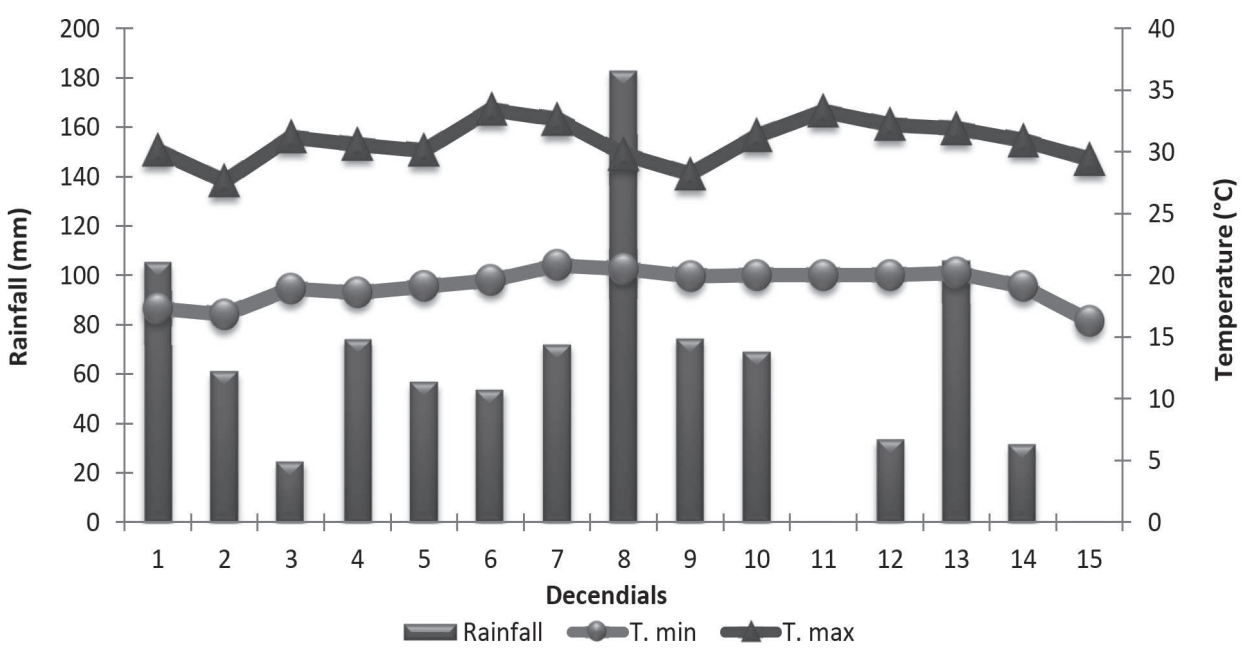

Figure 1: Representation of rainfall, minimum and maximum average temperature for the period referring to the maize crop cycle. Piracicaba - SP, 2016/17 season.

Source: LEB - USP/ESALQ.

Table 1: Soil chemical and physical analysis of the experimental area, at depth of 0 to $20 \mathrm{~cm}$. Piracicaba - SP, 2016/17 season

\begin{tabular}{|c|c|c|c|c|c|c|c|c|c|}
\hline \multicolumn{10}{|c|}{ Experiment I } \\
\hline $\mathrm{pH}\left(\mathrm{CaCl}_{2}\right)$ & Al & $\mathbf{H}+\mathbf{A l}$ & $\mathbf{P}($ resin $)$ & $\mathbf{K}$ & $\mathrm{Ca}$ & Mg & SB & CEC & $\mathbf{V}$ \\
\hline 5.3 & $<1.0$ & 25.0 & 10.0 & 2.8 & 26.0 & 13 & 41.8 & 66.8 & 63 \\
\hline \multicolumn{2}{|c|}{ Clay } & \multicolumn{4}{|c|}{ Silt } & \multicolumn{4}{|c|}{ Sand } \\
\hline \multicolumn{2}{|c|}{41.0} & \multicolumn{4}{|c|}{5.0} & \multicolumn{4}{|c|}{54.0} \\
\hline \multicolumn{10}{|c|}{ Experiment II } \\
\hline $\mathrm{pH}\left(\mathrm{CaCl}_{2}\right)$ & Al & $\mathbf{H}+\mathbf{A l}$ & $\mathbf{P}($ resin $)$ & $\mathbf{K}$ & $\mathbf{C a}$ & Mg & SB & CEC & $\mathbf{V}$ \\
\hline 5.3 & $<1.0$ & 25.0 & 7.0 & 2.6 & 39.0 & 16 & 57.6 & 82.8 & 70 \\
\hline \multicolumn{2}{|c|}{ Clay } & \multicolumn{4}{|c|}{ Silt } & \multicolumn{4}{|c|}{ Sand } \\
\hline \multicolumn{2}{|c|}{40.0} & \multicolumn{4}{|c|}{6.0} & \multicolumn{4}{|c|}{54.0} \\
\hline
\end{tabular}

Units: $\mathrm{Al}, \mathrm{H}+\mathrm{Al}, \mathrm{K}, \mathrm{Ca}, \mathrm{Mg}, \mathrm{SB}$ and $\mathrm{CEC}\left(\mathrm{mmol}_{\mathrm{c}} \mathrm{dm}^{-3}\right) ; \mathrm{P}$ (resin) $\left(\mathrm{mg} \mathrm{dm}^{-3}\right) ; \mathrm{V}$, clay, silt and sand $(\%)$. 
the scores were maintained for atrazine + nicosulfuron and mesotrione + nicosulfuron, whereas for nicosulfuron alone it increased to $7.5 \%$; in this evaluation, $5 \%$ was also observed for atrazine + tembotrione treatment, which remained until 21 DAA. At 28, 35 and 42 DAA, no more symptoms of injury were observed in maize plants, for the application of all treatments (Table 3).

For experiment II, at 7 DAA, treatments that caused injury to maize plants were nicosulfuron (3.5\%), tembotrione $(3 \%)$ and atrazine + mesotrione + nicosulfuron (3.5\%). At 14 DAA the score remained at $3 \%$ for tembotrione and reduced to $3 \%$ for the triple association. Whereas, at 21 DAA, the application that caused injury were atrazine + nicosulfuron $(3 \%)$, mesotrione + nicosulfuron $(4.5 \%)$, atrazine + tembotrione $(3 \%)$, atrazine + nicosulfuron $(3 \%)$ and mesotrione with a reduction to

Table 2: Treatments composed by the isolated or associated application of herbicides, in post emergence of maize. Piracicaba - SP, 2016/17 season

\begin{tabular}{ll}
\hline Treatments & \multicolumn{1}{c}{ Rates $^{1}$} \\
\hline control (with weeding) & - \\
control (without weeding) & - \\
atrazine & 1,500 \\
mesotrione & 168 \\
nicosulfuron & 50 \\
tembotrione & 100.8 \\
atrazine + mesotrione & $1,500+168$ \\
atrazine + nicosulfuron & $1,500+50$ \\
atrazine + tembotrione & $1,500+100.8$ \\
mesotrione + nicosulfuron & $168+50$ \\
atrazine + mesotrione + nicosulfuron & $1,500+168+50$ \\
\hline${ }^{1}$ Grams of active ingredient per hectare (g a.i. ha $\left.{ }^{-1}\right)$. \\
Comercial products: Gesaprin ${ }^{\circledR}$ GRDA (atrazine), Callisto ${ }^{\circledR}$ \\
(mesotrione), Sanson ${ }^{\circledR} \quad 40 \quad$ SC (nicosulfuron), Soberan ${ }^{\circledR}$ \\
(tembotrione).
\end{tabular}

$3.5 \%$ (Table 4). Thus, the crop injury was found in experiment I and experiment II up to 21 DAA, after this evaluation no symptoms were observed in all treatments.

There were differences in the height in the experiment II at 7 DAA, for the treatment atrazine + mesotrione + nicosulfuron, with a lower value at $8.38 \mathrm{~cm}$ in relation to the control. At 28 DAA, the lowest values were for mesotrione, atrazine + nicosulfuron, mesotrione + nicosulfuron and for atrazine + mesotrione + nicosulfuron. However, to the shoot dry mass, there was no difference between the means in relation to the control (without application) (Table 5).

At 14,21 and 28 DAA, atrazine + mesotrione + nicosulfuron, mesotrione + nicosulfuron, atrazine + tembotrione and atrazine + nicosulfuron provided the same weed control. At 7 DAA only the triple association was equal to the weed control, with control of $86.25 \%$. On the other hand, treatments with isolated herbicides and the association atrazine + mesotrione resulted in lower control than weed control in all evaluations (Table 6).

The total dry mass of weeds was higher for atrazine $(18.51 \mathrm{~g})$, mesotrione $(35.9 \mathrm{~g})$ and atrazine + mesotrione $(18.6 \mathrm{~g})$ treatments, in which the highest dry mass was monocotyledons with $17.98,26.61$ and $17.17 \mathrm{~g}$, respectively. However, for eudicotyledons weeds, the highest dry masses were observed in the treatments mesotrione $(9.29 \mathrm{~g})$, nicosulfuron $(6.61 \mathrm{~g})$ and tembotrione (3.76 g) (Table 7).

Maize yield was lower only when was applied mesotrione alone (Table 8), which can be explained by the low control of weeds, mainly monocotyledons.

\section{DISCUSSION}

Dan et al. (2011) also observed injury in maize hybrids submitted to nicosulfuron at rates of 50 and $60 \mathrm{~g}$ a.i. ha ${ }^{-1}$

Table 3: Evaluation of crop injury at 7, 14 and 21 days after application (DAA) of maize plants under isolated or associated application of herbicides (experiment I). Piracicaba - SP, 2016/17 season

\begin{tabular}{lccc}
\hline \multirow{2}{*}{ Treatments } & \multicolumn{1}{c}{ Crop injury (\%) } & $\mathbf{2 1}$ \\
\cline { 2 - 3 } control (with weeding) & $\mathbf{7}$ & $\mathbf{1 4}$ & 0.0 \\
control (without weeding) & 0.0 & 0.0 & 0.0 \\
atrazine & 0.0 & 0.0 & 0.0 \\
mesotrione & 0.0 & 0.0 & 0.0 \\
nicosulfuron & 0.0 & 0.0 & 0.0 \\
tembotrione & 6.8 & 7.5 & 0.0 \\
atrazine + mesotrione & 0.0 & 0.0 & 0.0 \\
atrazine + nicosulfuron & 0.0 & 0.0 & 5.0 \\
atrazine + tembotrione & 5.0 & 5.0 & 5.0 \\
mesotrione + nicosulfuron & 0.0 & 5.0 & 2.5 \\
atrazine + mesotrione + nicosulfuron & 6.3 & 6.3 & 5.0 \\
\hline & 0.0 & 0.0 & 1.6 \\
\hline
\end{tabular}

Rev. Ceres, Viçosa, v. 66, n.4, p. 279-286, jul/aug, 2019 
and in association of nicosulfuron + atrazine $(20+1,500$ and $40+3,000 \mathrm{~g}$ a.i. $\mathrm{ha}^{-1}$ ) at 14 DAA. The symptoms varied from 2.33 to $5 \%$ in the lowest rate of nicosulfuron, reaching $7 \%$ in the highest rate, agreeing with the verified in this work where the scores ranged from $6.75 \%$ at 7 DAA and $7.5 \%$ at $14 \mathrm{DAA}$. The authors attributed scores up to $2.33 \%$ in the lowest rates and up to $3 \%$ in the highest rates applied to the 14 DAA, for the associations. These scores are being close to those found in this study, in which the scores were up to $5 \%$, but with the hybrid different from that studied.

Weed control with atrazine $\left(2,400 \mathrm{~g}\right.$ a.i. ha $\left.{ }^{-1}\right)$ and mesotrione (192 $\mathrm{g}$ a.i. ha ${ }^{-1}$ ) isolated were studied by Philippi et al. (2016), that observed control of $58.75 \%$ and $32.5 \%$ for atrazine and mesotrione, respectively. The control may have been compromised due to the climatic conditions of high temperatures and low relative air humidity, reducing the effectiveness of the herbicides and raising the seed bank in the later crop, in which, they verified controls of $89.2 \%$ for atrazine and $85.6 \%$ for mesotrione.

In a study by Brown et al. (2016), the use of atrazine $\left(1,500 \mathrm{~g}\right.$ a.i. ha ${ }^{-1}$ ) for Conyza canadensis (eudicotyledon weed) resulted in a control of $48 \%$ in the evaluation of 8 weeks after application, when in association with the mesotrione the control reached $97 \%$. As in this study, that the control with atrazine alone was $46.25 \%$ and $10 \%$ for mesotrione at 42 DAA. However, in this study, the weed control with atrazine + mesotrione resulted in efficacy of only $45 \%$, which is explained by the high presence of monocotyledons weeds, with dry mass of $26.61 \mathrm{~g}$.

Table 4: Evaluation of crop injury at 7, 14, 21 and 28 days after application (DAA) of maize plants under isolated or associated application of herbicides (experiment II). Piracicaba - SP, 2016/17 season

\begin{tabular}{|c|c|c|c|}
\hline \multirow{2}{*}{ Treatments } & \multicolumn{3}{|c|}{ Crop injury (\%) } \\
\hline & 7 & 14 & 21 \\
\hline control & 0.0 & 0.0 & 0.0 \\
\hline atrazine & 0.0 & 0.0 & 0.0 \\
\hline mesotrione & 0.0 & 0.0 & 0.0 \\
\hline nicosulfuron & 3.5 & 0.8 & 0.0 \\
\hline tembotrione & 3.0 & 3.0 & 0.0 \\
\hline atrazine + mesotrione & 3.0 & 3.0 & 0.0 \\
\hline atrazine + nicosulfuron & 0.0 & 3.0 & 0.0 \\
\hline atrazine + tembotrione & 0.0 & 3.0 & 0.0 \\
\hline mesotrione + nicosulfuron & 0.0 & 4.5 & 3.5 \\
\hline atrazine + mesotrione + nicosulfuron & 3.5 & 3.0 & 0.0 \\
\hline Mean & 1.3 & 2.0 & 0.4 \\
\hline
\end{tabular}

Table 5: Height and dry mass of shoot of maize plants under isolated or associated application of herbicides (experiment II). Piracicaba - SP, 2016/17 season

\begin{tabular}{|c|c|c|c|c|c|}
\hline \multirow{2}{*}{ Treatments } & \multicolumn{4}{|c|}{ Height (cm) } & \multirow{2}{*}{$\frac{\text { Shoot }}{\text { dry mass (g) }}$} \\
\hline & 7 & 14 & 21 & 28 & \\
\hline control & $29.63 \mathrm{a}$ & 39.75 & 59.75 & $85.13 \mathrm{ab}$ & 38.91 \\
\hline atrazine & $24.88 \mathrm{ab}$ & 46.13 & 61.63 & $86.13 \mathrm{ab}$ & 42.24 \\
\hline mesotrione & $22.50 \mathrm{ab}$ & 40.38 & 43.50 & $73.75 \mathrm{~d}$ & 38.04 \\
\hline nicosulfuron & $22.88 \mathrm{ab}$ & 41.63 & 55.88 & $89.38 \mathrm{a}$ & 41.08 \\
\hline tembotrione & $27.50 \mathrm{ab}$ & 44.88 & 55.25 & $84.50 \mathrm{ab}$ & 42.15 \\
\hline atrazine + mesotrione & $23.25 \mathrm{ab}$ & 38.38 & 51.50 & $87.75 \mathrm{ab}$ & 43.24 \\
\hline atrazine + nicosulfuron & $25.50 \mathrm{ab}$ & 41.75 & 56.25 & $81.00 \mathrm{bc}$ & 35.98 \\
\hline atrazine + tembotrione & $23.13 \mathrm{ab}$ & 38.50 & 49.88 & $75.50 \mathrm{~cd}$ & 36.38 \\
\hline mesotrione + nicosulfuron & $24.63 \mathrm{ab}$ & 43.88 & 59.63 & $91.00 \mathrm{a}$ & 43.61 \\
\hline atrazine + mesotrione + nicosulfuron & $21.25 \mathrm{~b}$ & 39.25 & 44.25 & $74.50 \mathrm{~cd}$ & 32.83 \\
\hline $\begin{array}{l}\text { Mean } \\
\end{array}$ & 24.51 & 41.45 & 53.75 & 82.86 & 39.34 \\
\hline $\mathrm{CV}(\%)$ & 12.44 & 11.04 & 18.04 & 3.49 & 13.58 \\
\hline $\mathrm{F}$ & $2.70 *$ & $0.95^{\mathrm{ns}}$ & $1.01^{\mathrm{ns}}$ & $0.59 *$ & $0.42^{\mathrm{ns}}$ \\
\hline
\end{tabular}

* Means followed by the same letter in the column do not differ statistically from each other by the Tukey's (1949) test $(p<0.05)$. ns not significant, means do not differ statistically from each other by the F-test $(p<0.05)$. 
The weed control in conventional maize with nicosulfuron (35 $\mathrm{g}$ a.i. $\mathrm{ha}^{-1}$ ) in V4 stage, sequential application of nicosulfuron ( $35 \mathrm{~g}$ a.i. ha $\left.{ }^{-1}\right)$ in V4 and V6 and nicosulfuron ( $35 \mathrm{~g}$ a.i. ha $\left.{ }^{-1}\right)+$ metolachlor $(1,120 \mathrm{~g}$ a.i. ha $\left.^{-1}\right)$ in V4, resulted in 61,66 and $68 \%$ control, respectively. The use of residual herbicides is necessary to obtain better results (Burke et al., 2008). In the present study, although nicosulfuron did not cause symptoms of injury after 21 DAA, the control percentage reached a maximum of $80 \%$ (21 DAA).

Janak \& Grichar (2016) studied the use of herbicides, at pre-emergence, to control monocotyledons and eudicotyledons weeds in maize. The authors found at 42 DAA that control for Brachiaria reptans was $40 \%$ when using atrazine, $93 \%$ for s-metolachlor and $82 \%$ when both herbicides were associated. They also verified $90 \%$ control for this species when they associated s-metolachlor + atrazine + mesotrione. In addition, all treatments used resulted in injury symptoms of less than $3 \%$ and did not affect crop yield.

The control of E. crus-galli, Urochloa ramosa and $I$. hederacea with tembotrione ( $92 \mathrm{~g}$ a.i. ha $\mathrm{a}^{-1}$ ) was 86,84 and $87 \%$, respectively, at 28 DAA. In the treatments with atrazine $\left(2,240 \mathrm{~g}\right.$ a.i. ha $\left.{ }^{-1}\right)$ were 80,78 and $95 \%$ to the same

Table 6: Weed control at 7, 14, 21, 28, 35 and 42 days after application (DAA) of maize plants under isolated or associated application of herbicides (experiment I), Piracicaba - SP, 2016/17 season

\begin{tabular}{|c|c|c|c|c|c|c|}
\hline \multirow{2}{*}{ Treatments } & \multicolumn{6}{|c|}{ Control (\%) } \\
\hline & 7 & 14 & 21 & 28 & 35 & 42 \\
\hline control (with weeding) & $100.00 \mathrm{a}$ & $100.00 \mathrm{a}$ & $100.00 \mathrm{a}$ & $100.00 \mathrm{a}$ & $100.00 \mathrm{a}$ & $100.00 \mathrm{a}$ \\
\hline control (without weeding) & $0.00 \mathrm{~h}$ & $0.00 \mathrm{f}$ & $0.00 \mathrm{e}$ & $0.00 \mathrm{e}$ & $0.00 \mathrm{~d}$ & $0.00 \mathrm{e}$ \\
\hline atrazine & $66.25 \mathrm{def}$ & $63.75 \mathrm{~cd}$ & $58.75 \mathrm{c}$ & $55.00 \mathrm{~d}$ & $50.00 \mathrm{c}$ & $46.25 \mathrm{~d}$ \\
\hline mesotrione & $41.25 \mathrm{~g}$ & $40.00 \mathrm{e}$ & $35.00 \mathrm{~d}$ & $20.00 \mathrm{e}$ & $10.00 \mathrm{~d}$ & $10.00 \mathrm{e}$ \\
\hline nicosulfuron & $68.75 \mathrm{cde}$ & $71.25 \mathrm{bc}$ & $80.00 \mathrm{~b}$ & $78.75 \mathrm{bc}$ & $78.75 \mathrm{~b}$ & $70.00 \mathrm{bc}$ \\
\hline tembotrione & $53.75 \mathrm{efg}$ & $51.25 \mathrm{de}$ & $53.75 \mathrm{~cd}$ & $58.75 \mathrm{~cd}$ & $61.25 \mathrm{c}$ & $61.25 \mathrm{~cd}$ \\
\hline atrazine + mesotrione & $51.25 \mathrm{fg}$ & $53.75 \mathrm{cde}$ & $53.75 \mathrm{~cd}$ & $46.25 \mathrm{~d}$ & $45.00 \mathrm{c}$ & $45.00 \mathrm{~d}$ \\
\hline atrazine + nicosulfuron & $77.50 \mathrm{bcd}$ & $85.00 \mathrm{ab}$ & $88.75 \mathrm{ab}$ & $90.00 \mathrm{ab}$ & $92.50 \mathrm{ab}$ & $89.25 \mathrm{ab}$ \\
\hline atrazine + tembotrione & $83.75 \mathrm{bc}$ & $89.25 \mathrm{ab}$ & $91.75 \mathrm{ab}$ & $92.25 \mathrm{ab}$ & $92.25 \mathrm{ab}$ & $90.75 \mathrm{ab}$ \\
\hline mesotrione + nicosulfuron & $77.50 \mathrm{bcd}$ & $85.00 \mathrm{ab}$ & $90.00 \mathrm{ab}$ & $90.00 \mathrm{ab}$ & $87.50 \mathrm{ab}$ & $86.25 \mathrm{ab}$ \\
\hline atrazine + mesotrione + nicosulfuron & $86.25 \mathrm{ab}$ & $95.00 \mathrm{a}$ & $95.50 \mathrm{ab}$ & $96.00 \mathrm{ab}$ & $96.50 \mathrm{ab}$ & $96.00 \mathrm{ab}$ \\
\hline Mean & 64.20 & 66.75 & 67.93 & 66.10 & 64.88 & 63.16 \\
\hline $\mathrm{CV}(\%)$ & 10.04 & 11.55 & 11.87 & 12.65 & 10.56 & 12.87 \\
\hline $\mathrm{F}$ & $53.55^{*}$ & $51.36 *$ & $50.05 *$ & $49.22 *$ & $68.13^{*}$ & 49.06* \\
\hline
\end{tabular}

* Means followed by the same letter in the column do not differ statistically from each other by the Tukey's $(1949)$ test $(p<0.05)$.

Table 7: Shoot dry mass of weeds monocotyledons, eudicotyledons and total under isolated or associated application of herbicides (experiment I), Piracicaba - SP, 2016/17 season

\begin{tabular}{|c|c|c|c|}
\hline \multirow{2}{*}{ Treatments } & \multicolumn{3}{|c|}{ Dry mass (g) } \\
\hline & MONO$^{1}$ & EUDI $^{1}$ & Total \\
\hline control (with weeding) & $0.00 \mathrm{a}$ & $0.00 \mathrm{a}$ & $0.00 \mathrm{a}$ \\
\hline control (without weeding) & $25.33 \mathrm{bc}$ & $18.30 \mathrm{f}$ & $43.63 \mathrm{c}$ \\
\hline atrazine & $17.98 \mathrm{~b}$ & $0.53 \mathrm{ab}$ & $18.51 \mathrm{~b}$ \\
\hline mesotrione & $26.61 \mathrm{c}$ & $9.29 \mathrm{e}$ & $35.90 \mathrm{c}$ \\
\hline nicosulfuron & $2.09 \mathrm{a}$ & $6.61 \mathrm{~d}$ & $8.70 \mathrm{a}$ \\
\hline tembotrione & $1.64 \mathrm{a}$ & $3.76 \mathrm{~b}$ & $5.40 \mathrm{a}$ \\
\hline atrazine + mesotrione & $17.17 \mathrm{~b}$ & $1.43 \mathrm{ab}$ & $18.60 \mathrm{~b}$ \\
\hline atrazine + nicosulfuron & $2.06 \mathrm{a}$ & $1.04 \mathrm{ab}$ & $2.24 \mathrm{a}$ \\
\hline atrazine + tembotrione & $0.77 \mathrm{a}$ & $1.42 \mathrm{ab}$ & $2.19 \mathrm{a}$ \\
\hline mesotrione + nicosulfuron & $0.17 \mathrm{a}$ & $2.07 \mathrm{bc}$ & $2.24 \mathrm{a}$ \\
\hline atrazine + mesotrione + nicosulfuron & $0.86 \mathrm{a}$ & $0.61 \mathrm{ab}$ & $1.47 \mathrm{a}$ \\
\hline Mean & 8.60 & 4.09 & 12.62 \\
\hline $\mathrm{CV}(\%)$ & 14.39 & 7.71 & 11.88 \\
\hline $\mathrm{F}$ & $13.38^{*}$ & $8.12 *$ & $11.02 *$ \\
\hline
\end{tabular}

${ }^{1}$ MONO - monocotyledons. EUDI - eudicotyledons.

* Means followed by the same letter in the column do not differ statistically from each other by the Tukey's $(1949)$ test $(p<0.05)$.

Rev. Ceres, Viçosa, v. 66, n.4, p. 279-286, jul/aug, 2019 
Table 8: Agronomic performance variables of maize plants under isolated or associated application of herbicides (experiment I). Piracicaba - SP, 2016/17 season

\begin{tabular}{|c|c|c|c|c|c|}
\hline Treatments & PH & EH & PI & YIELD $^{1}$ & GM \\
\hline control (with weeding) & 2.38 & 1.35 & 1.20 & $10.89 \mathrm{a}$ & 271.03 \\
\hline control (without weeding) & 2.35 & 1.35 & 1.40 & $7.91 \mathrm{~b}$ & 279.86 \\
\hline atrazine & 2.42 & 1.40 & 1.10 & $9.14 \mathrm{ab}$ & 279.86 \\
\hline mesotrione & 2.33 & 1.35 & 1.25 & $7.85 \mathrm{~b}$ & 266.87 \\
\hline nicosulfuron & 2.33 & 1.37 & 1.28 & $9.16 \mathrm{ab}$ & 273.44 \\
\hline tembotrione & 2.38 & 1.35 & 1.28 & $8.40 \mathrm{ab}$ & 276.06 \\
\hline atrazine + mesotrione & 2.39 & 1.38 & 1.25 & $9.60 \mathrm{ab}$ & 265.10 \\
\hline atrazine + nicosulfuron & 2.33 & 1.37 & 1.50 & $10.53 \mathrm{a}$ & 290.31 \\
\hline atrazine + tembotrione & 2.40 & 1.37 & 1.20 & $10.79 \mathrm{a}$ & 282.57 \\
\hline mesotrione + nicosulfuron & 2.32 & 1.34 & 1.28 & $10.11 \mathrm{ab}$ & 296.89 \\
\hline atrazine + mesotrione + nicosulfuron & 2.41 & 1.37 & 1.23 & $10.80 \mathrm{a}$ & 281.21 \\
\hline Mean & 2.37 & 1.36 & 1.27 & 9.56 & 277.34 \\
\hline$\overline{\mathrm{CV}}(\%)$ & 3.60 & 3.33 & 14.90 & 11.15 & 6.27 \\
\hline F & $0.71^{\mathrm{ns}}$ & $0.61^{\mathrm{ns}}$ & $1.29^{\mathrm{ns}}$ & $4.71 *$ & $1.35^{\mathrm{ns}}$ \\
\hline
\end{tabular}

PH - plant height (m), EA - ear insertion height (m), PI - prolificacy index (plant ears $\left.{ }^{-1}\right)$, YIELD (t ha $\left.{ }^{-1}\right)$, GM $^{-} 1,000$ grains mass $(\mathrm{g})$.

* Means followed by the same letter in the column do not differ statistically from each other by the Tukey's $(1949)(p<0.05)$. ns - not significant, means do not differ statistically from each other by the F-test $(p<0.05)$.

species. When the two herbicides were associated, the control obtained was 94,92 and $96 \%$. It was verified control of $43 \%$ for Sorghum halepense when only tembotrione was used and $39 \%$ for the application of atrazine isolated, but in the combination of herbicides this control was $73 \%$. For A. palmeri, the two isolated or associated herbicides obtained controls above $92 \%$ (Stephenson IV et al., 2015). As in this work, the use of tembotrione and its association with atrazine did not reduce maize yield.

Several studies highlight the efficacy of glyphosate, in different associations, for weed control in maize, with control of different weeds around 90\% (Patches et al., 2017; Chahal et al., 2018; Chahal \& Jhala, 2018; Kaur \& Jhala, 2018). This same control level was observed in this study for the application of atrazine + nicosulfuron, atrazine + tembotrione, mesotrione and nicosulfuron + atrazine + nicosulfuron + mesotrione without the use of glyphosate.

These results indicate that in certain situations effective weed management in maize is possible even without glyphosate. This herbicide is very important in different crops for weed control, but the characterization of alternative treatments is very important in the management and prevention of selection of glyphosate-resistant biotypes. As highlighted by several studies, management with alternative herbicides to glyphosate is necessary to assist in the management of herbicide resistance to weed resistance (Heap \& Duke, 2018; Neve et al., 2018; Rosario-Lebron et al., 2019).
In addition, the associations help in effective control, mainly of monocotyledons, helping to maintain the maize yield, as observed in this study. Other studies also highlight the importance of using glyphosate alternative herbicides in maize, highlighting atrazine and/or nicosulfuron (Ganie et al., 2017; Chahal \& Jhala, 2018; Galon et al., 2018).

\section{CONCLUSIONS}

The post-emergence (V4) application of atrazine, nicosulfuron, mesotrione and tembotrione, applied alone and associated was selective to the conventional maize hybrid 30F53.

The herbicides atrazine, nicosulfuron, mesotrione and tembotrione, at associations, were effective in the weed control, except the association atrazine + mesotrione.

\section{ACKNOWLEDGEMENTS, FINANCIAL SUPPORT AND FULL DISCLOSURE}

There is not any conflict of interests in carrying the research and publishing the manuscript.

\section{REFERENCES}

Borém A, Galvão JCC \& Pimentel MA (2015) Milho: do plantio à colheita. $1^{a}$ ed. Viçosa, Editora UFV. 351p.

Brown LR, Shropshire C \& Sikkema PH (2016) Control of glyphosate-resistant Canada fleabane in corn with preplant herbicides. Canadian Journal of Plant Science, 96:932-934.

Burke IC, Thomas WE, Allen JR, Collins J \& Wilcut JW (2008) A comparison of weed control in herbicide-resistant, herbicidetolerant, and conventional corn. Weed Technology, 22:571-579. 
Chahal PS \& Jhala AJ (2018) Economics of management of photosystem II- and HPPD-inhibitor-resistant palmer amaranth in corn. Agronomy Journal, 110:1905-1914.

Chahal PS, Ganie ZA \& Jhala AJ (2018) Overlapping residual herbicides for control of photosystem (PS) II-and 4hydroxyphenylpyruvate dioxygenase (HPPD)-inhibitorresistant palmer amaranth (Amaranthus palmeri S. Watson) in glyphosate-resistant maize. Frontiers in Plant science, 8:2231.

CONAB - Companhia Nacional de Abastecimento (2019) Acompanhamento da safra brasileira: Grãos: Safra 2018/19, quinto levantamento, fevereiro de 2019. Brasília, CONAB. 122p.

Correa MJP \& Alves PLCA (2009) Efficacy of herbicides applied in post emergence on conventional and transgenic soybean. Planta Daninha, 27:1035-1046.

Dan HA, Lemos Barroso AL, Braz GBP, Moraes Dan LG, Ferreira Filho WC, Menezes CCE \& Azambuja US (2011) Seletividade do nicosulfuron e da mistura com atrazine na cultura do milho. Agrarian, 3:243-252.

Fancelli AL \& Dourado Neto D (2000) Produção de Milho. Guaíba, Editora Agropecuária. 360p.

Ferreira DF (2011) Sisvar: a computer statistical analysis system. Ciência e Agrotecnologia, 35:1039-1042.

Galon L, David FA, Forte CT, Júnior FWR, Radunz AL, Kujawinski R, Radunz LL, Castoldi CT, Perin GF \& Mossi AJ (2018) Chemical management of weeds in corn hybrids. Weed Biology and Management, 18:26-40.

Ganie ZA, Lindquist JL, Jugulam M, Kruger GR, Marx DB \& Jhala AJ (2017) An integrated approach to control glyphosate resistant Ambrosia trifida with tillage and herbicides in glyphosate resistant maize. Weed Research, 57:112-122.

Gazziero DLP (2015) Mixtures of pesticides in tank, in Brazilian farms. Planta Daninha, 33:83-92.

Giovanelli BF, Silva AFM, Albrecht AJP, Aiello LHF, Ghirardello GA, Albrecht LP \& Victoria Filho R (2018) Selectivity of herbicides applied separately or in combination in the post emergence of RR2 maize. Brazilian Journal of Agriculture, 93:4757.

Green JM (2012) The benefits of herbicide-resistant crops. Pest Management Science, 68:1323-1331

Heap I \& Duke SO (2018) Overview of glyphosate resistant weeds worldwide. Pest Management Science, 74:1040-1049.

Heap I (2019) International survey of herbicide resistant weeds. Available at: 〈http://www.weedscience.org>. Accessed on: August $12^{\text {th }}, 2019$.

Janak TW \& Grichar WJ (2016) Weed control in corn (Zea mays $\mathrm{L}$, ) as influenced by preemergence herbicides. International Journal of Agronomy, 2016:01-09.

Kaur S \& Jhala AJ (2018) Control of glyphosate-resistant giant ragweed (Ambrosia trifida L.) with premix of iodosulfuron/ thiencarbazone applied alone or in tank mixtures in no-till corn (Zea mays L.). Canadian Journal of Plant Science, 98:908917.
Neve P, Barney JN, Buckley Y, Cousens RD, Graham S, Jordan NR, Shaw J, Lawton Rauh A, Liebman M, Mesgaran MB, Schut M, Shaw J, Storkey J, Baraibar B, Baucom RS, Chalak M, Childs DZ, Christensen S, Eizenberg H, Fernández Quintanilla C, French K, Harsch M, Heijting S, Harrison L, Loddo D, Macel M, Maczey N, Mortensen D, Necajeva J, Peltzer DA, Recasens J, Renton M, Riemens M, Sønderskov M \& Williams M (2018) Reviewing research priorities in weed ecology, evolution and management: a horizon scan. Weed Research, 58:250-258.

Oliveira Júnior RS (2011) Mecanismos de Ação dos Herbicidas. In: Oliveira Júnior RS, Constantin J \& Inoue MH (Ed.) Biologia e Manejo de Plantas Daninhas. Curitiba, Ominipax. p.141-192.

Oliveira Neto AM, Constantin J, Júnior RSO, Guerra N, Braz GBP, Vilela LMS, Botelho LVP \& Ávila LA (2013) Sistemas de dessecação em áreas de trigo no inverno e atividade residual de herbicidas na soja. Revista Brasileira de Herbicidas, 12:14-22.

Patches KM, Curran WS \& Lingenfelter DD (2017) Effectiveness of herbicides for control of common pokeweed (Phytolacca americana) in cor $\mathrm{n}$ and soybean. Weed Technology, 31:193201 .

Philippi E, Ternus RM, Cavalcante JÁ \& Fraga AM (2016) Desempenho de herbicidas no controle de plantas daninhas em milho silagem. Revista Verde de Agroecologia e Desenvolvimento Sustentável, 11:01-06.

Pimentel-Gomes F \& Garcia CH (2002) Estatística aplicada a experimentos agronômicos e florestais: exposição com exemplos e orientações para uso de aplicativos. Piracicaba, FEALQ. 309 p.

Ramires AC, Constantin J, Oliveira Júnior RS, Guerra N, Alonso DG \& Biffe DF (2010) Control of Euphorbia heterophylla and Ipomoea grandifolia using glyphosate isolated or in association with broadleaf herbicides. Planta Daninha, 28:621-629.

Riar DS, Norsworthy JK, Steckel LE, Stephenson DO, Eubank TW, Bond J \& Scott RC (2013) Adoption of best management practices for herbicide-resistant weeds in midsouthern United States cotton, rice, and soybean. Weed Technology, 27:788797.

Rodrigues BN \& Almeida FS (2018) Guia de herbicidas. $7^{\text {th }}$ ed. Londrina, Editing authors. 764p.

Rosario-Lebron A, Leslie AW, Yurchak VL, Chen G \& Hooks CR (2019) Can winter cover crop termination practices impact weed suppression, soil moisture, and yield in no-till soybean [Glycine $\max$ (L.) Merr.]? Crop Protection, 116:132-141.

Stephenson IV DO, Bond JA, Landry RL \& Edwards HM (2015) Weed management in corn with postemergence applications of tembotrione or thiencarbazone: tembotrione. Weed Technology, 29:350-358.

Soltani N, Van Eerd LL, Vyn RJ, Shropshire C \& Sikkema PH (2010) Weed control, environmental impact and profitability with glyphosate tank mixes in glyphosate-tolerant corn. Canadian Journal of Plant Science, 90:125-132.

Tukey JW (1949) Comparing individual means in the analysis of variance. Biometrics, 5:99-114.

Velini ED, Osipe R \& Gazziero DLP (1995) Procedimentos para instalação, avaliação e análise de experimentos com herbicidas. Londrina, SBCPD. 42p. 